\title{
Hubungan Iklim Organisasi dan Komitmen Terhadap Organisasi Dengan Mempertimbangkan Lama Kerja (Studi Pada Staf Pengajar dan Pendukung di Universitas Swasta X Jakarta)
}

\author{
Sukma Rani \\ Program Studi Psikologi, Fakultas Psikologi, Universitas Padjadjaran Bandung \\ sukmarani78@gmail.com \\ Hendriati Agustiani \\ Program Studi Psikologi, Fakultas Psikologi, Universitas Padjadjaran Bandung \\ tiawiraatmadja@yahoo.com \\ Maya Rosmawati Ardiwinata \\ Program Studi Psikologi, Fakultas Psikologi, Universitas Padjadjaran Bandung \\ mayardiwi@gmail.com \\ R. Urip Purwono \\ Program Studi Psikologi, Fakultas Psikologi, Universitas Padjadjaran Bandung \\ urip.purwono@gmail.com
}

\begin{abstract}
This study aim is to find the correlation between organizational climate and organizational commitment with considering the employee's tenure. The subjects of this study were 94 employees of X private university. This study used purposive sampling. Researcher used organizational climate scale and organizational commitment scale which has been developed by Susanty (2012). The result of this study using Spearman Correlation showed $r=0,694$ with $p=0,000<0,05$. It shows that there is a signigicant and positive correlation between organizational climate and organizational commitment. The result from considering the employee's tenure is a significant and positive correlation between organizational climate and organizational commitment from two tenure groups of participants. From these results, it is concluded that the hypothesis stating there is a positive correlation between organizational climate and organizational commitment is acceptable.
\end{abstract}

Keywords: organizational climate; organizational commitment; university

\begin{abstract}
Abstrak
Tujuan penelitian untuk mengetahui hubungan antara iklim organisasi dan komitmen terhadap organisasi dengan mempertimbangkan variabel lama bekerja.
\end{abstract}


Subjek penelitian melibatkan 94 karyawan di Universitas Swasta X. Pengambilan sampel menggunakan teknik purposive sampling. Metode pengambilan data menggunakan skala iklim organisasi dan skala komitmen terhadap organisasi yang dikembangkan oleh Susanty (2012). Dari hasil perhitungan menggunakan Spearman Correlation diperoleh $r=0,694$ dengan $p=0,000<0,05$. Dengan demikian dapat dikatakan bahwa terdapat hubungan yang signifikan dan positif antara iklim organisasi dan komitmen terhadap organisasi. Penelitian ini mempertimbangkan faktor lama bekerja, dengan hasil terdapat hubungan yang signifikan dan positif antara iklim organisasi dan komitmen terhadap organisasi pada kelompok partisipan yang memiliki lama bekerja dari 1 hingga 10 tahun dengan nilai $r=0,701$ dan $p=0,000$. Serta hubungan positif dan signifikan pada kelompok lama bekerja dari 11 hingga 20 tahun dengan nilai $r=0,783$ dan $p=$ 0,002 .

Kata kunci: iklim organisasi; komitmen terhadap organisasi; universitas

\section{Pendahuluan}

Undang-Undang nomor 12 Tahun 2012 mendefinisikan pendidikan tinggi sebagai jenjang pendidikan yang mencakup program spesialis, magister, diploma, dan sarjana yang diadakan oleh perguruan tinggi berdasarkan kebudayaan Indonesia. Dalam proses penyelenggaraannya, pendidikan tinggi menjalankannya berdasarkan asas Tridharma perguruan tinggi. Dalam proses menjalankannya tentu pendidikan tinggi terutama Universitas tidak terlepas dari adanya peran sumber daya manusia (SDM).

Sumber daya manusia dalam universitas mencakup para dosen sebagai staf pengajar dan juga karyawan lain sebagai pendukung. Apabila staf pengajar dan pendukung memiliki kinerja yang baik tentu hal ini akan memberikan dampak positif bagi pihak universitas (Permarupan, Saufi, Kasim, Balakrishnan, 2013). Penelitian yang dilakukan oleh Junandi (2012) memaparkan bahwa kinerja SDM juga dipengaruhi oleh iklim organisasi. Hal ini membuat peneliti tertarik untuk meneliti iklim organisasi dalam lingkup Universitas.

Iklim organisasi merupakan kebermaknaan yang dirasakan oleh anggota organisasi dan berhubungan dengan kebijakan serta prosedur di dalam suatu organisasi (Schneider, 2013). Salah satu faktor yang erat kaitannya dengan iklim organisasi adalah komitmen terhadap organisasi. Komitmen terhadap organisasi 
merupakan hubungan psikologis antara karyawan dengan organisasi yang menyebabkan karyawan merasa ingin terus bekerja demi organisasinya sehingga karyawan tersebut tidak meninggalkan organisasi tempat ia bekerja (Miroshnik, 2013).

Penelitian-penelitian mengenai iklim organisasi dan komitmen terhadap organisasi pun terus mengalami perkembangan. Penelitian yang dilakukan oleh Ausri, Susilo dan Sulistyo (2018) mengenai iklim organisasi dan komitmen terhadap organisasi menghasilkan hubungan yang positif serta signifikan. Beberapa penelitian lainnya, seperti dalam industri tekstil yang dilakukan oleh Rahmawati \& Prasetyo (2017) dan manufaktur mesin dan industri transportasi yang dilakukan oleh Carpicornia (2012) juga memperlihatkan adanya hubungan yang signifikan dan positif antara iklim organisasi dan komitmen organisasi. Penelitian berikutnya yang dilakukan di perusahaan telekomunikasi, hasilnya juga menunjukkan bahwa iklim dan komitmen organisasi saling berhubungan (Kambey, Adolfina, \& Trang, 2016).

Tak hanya dilakukan dalam lingkup perusahaan, penelitian mengenai iklim organisasi dan komitmen terhadap organisasi juga mulai dikembangkan pada lingkup Universitas. Permarupan dan rekan-rekannya (2013) melakukan penelitian pada salah satu Universitas yang ada di Malaysia juga menunjukkan bahwa terdapat hubungan antara iklim organisasi dan komitmen organisasi. Penelitian lainnya yang dilakukan oleh Hosseini dan Talebian (2015) pada salah satu Universitas yang ada di Malaysia menunjukkan adanya hubungan yang signifikan serta positif antara iklim organisasi. Berbeda dengan hasil penelitian Hosseini dan Talebian (2015) serta Permarupan et al (2013), penelitian yang dilakukan oleh Adeniji (2011) pada universitas swasta di Nigeria menunjukkan tidak adanya hubungan antara iklim organisasi dengan komitmen terhadap organisasi. Penelitian ini mempertimbangkan faktor lain dengan menggunakan variabel tambahan seperti jenis kelamin, lama bekerja, dan usia. Dari penelitianpenelitian tersebut, tampak bahwa penelitian mengenai iklim organisasi dan komitmen terhadap organisasi dalam lingkup universitas mulai dilakukan di Universitas, terutama selain di Indonesia. Perbedaan hasil dari penelitian- 
penelitian sebelumnya terkait iklim organisasi dan komitmen terhadap organisasi di universitas, serta belum didapatkan literatur keadaannya di lingkup Indonesia, maka hal ini mendorong peneliti untuk meneliti hubungan antara iklim organisasi dengan komitmen terhadap organisasi pada universitas swasta di Jakarta.

Kingkin, Rosyid, dan Arianggi (2016) menemukan bahwa adanya hubungan yang signifikan serta positif antara lama bekerja dengan komitmen terhadap organisasi dalam lingkup perusahaan. Penelitian lain yang dilakukan oleh Suryani (2018) juga menemukan bahwa lama bekerja juga memengaruhi komitmen terhadap organisasi karyawan. Oleh karena itu, peneliti ingin meneliti hubungan antara iklim psikologis dan komitmen terhadap organisasi pada karyawan Universitas X dengan mempertimbangkan variabel lama bekerja.

Peneliti melakukan wawancara sebagai bentuk dari studi pendahuluan di salah satu universitas swasta di Jakarta yang akan peneliti jadikan tempat untuk mengumpulkan data. Dalam melakukan studi pendahuluan ini, peneliti meminta kesediaan empat partisipan yang masing-masing terdiri dari dua staf pengajar dan juga staf pendukung di Universitas X. Partisipan pertama mengatakan bahwa iklim organisasi di lingkup Universitas $\mathrm{X}$ sudah cukup baik namun dukungan dan juga penghargaan pada lingkup Universitas masih perlu ditingkatkan. Sedangkan untuk komitmen organisasi, ia mengatakan bahwa dirinya bekerja karena mendapatkan gaji dan fasilitas yang lebih baik dari organisasi sebelumnya. Bisa dikatakan bahwa partisipan pertama bekerja berdasarkan komitmen berkelanjutan.

Partisipan kedua merupakan seorang staf pengajar. Ia mengatakan bahwa secara keseluruhan iklim organisasi di Universitas X sudah terpenuhi. Namun hal yang paling disoroti adalah mengenai dukungan yang ia terima terutama dari para teman serta koleganya. Ia juga mengatakan bahwa dirinya merasa sangat senang bekerja di Universitas $X$ dan sudah menganggap semua orang yang ada di tempat kerja sudah seperti keluarganya sendiri. Hal ini menunjukkan bahwa partisipan kedua bekerja berdasarkan komitmen afektif.

Partisipan ketiga merupakan seorang staf pendukung merasakan bahwa iklim organisasi Universitas X sudah cukup baik. Hal yang paling menonjol adalah mengenai dukungan yang dirinya dapatkan dari teman-teman kerjanya, 
perasaan sangat senang bekerja universitas $X$, dan memiliki kelekatan emosional dengan tempat bekerjanya. Dari hasil tersebut tampak komitmen organisasi yang dirasakan oleh partisipan ketiga adalah komitmen afektif.

Partisipan keempat merupakan staf pengajar yang sudah cukup lama mengajar di Universitas X. Ia merasa bahwa dirinya kurang merasakan iklim organisasi yang baik. Ia juga merasa dirinya kurang mendapatkan penghargaan dan dukungan padahal ia sudah bekerja cukup lama di Universitas X. Dapat dikatakan bahwa partisipan keempat kurang memiliki komitmen terhadap organisasi, namun diperkirakan memiliki faktor lain yang membuat ia tetap bekerja di organisasi tersebut.

Idealnya iklim organisasi yang baik adalah terpenuhinya seluruh dimensi iklim organisasi (Schneider, 2013). Sedangkan untuk komitmen organisasi juga bisa dikatakan baik apabila seluruh dimensi dari komitmen organisasi dapat semuanya terpenuhi (Miroshnik, 2013).

\section{Iklim Organisasi}

Iklim organisasi awalnya berasal dari Social Exchange Theory yang menekankan adanya hubungan timbal balik antara pihak yang satu dengan pihak lain. Teori ini dipopulerkan oleh Peter Blau dan Kahn pada tahun 1990 dan selanjutnya dikembangkan oleh Meyer pada tahun 1968. Schneider (2013) kemudian mengembangkan teori iklim organisasi yang telah dikembangkan oleh Meyer (1968). Definisi mengenai iklim organisasi menurut Schneider (2013) adalah kebermaknaan yang dirasakan oleh anggota organisasi dan berhubungan dengan kebijakan serta prosedur di dalam suatu organisasi. Dimensi dari iklim organisasi pun dibagi menjadi empat hal yang terdiri dari komitmen kelompok, dukungan kelompok, standar serta struktur.

Dimensi struktur dalam organisasi berdampak pada iklim organisasi dalam hal kompleksitas hierarki. Apabila suatu organisasi memiliki jenjang struktur yang sangat banyak, maka komunikasi antara divisi yang satu dengan divisi yang lain akan menjadi terhambat. Komunikasi dalam organisasi yang terhambat ini tentunya akan berdampak kepada iklim organisasi (Scheider, 2013). 
Dimensi standar memengaruhi iklim organisasi dalam hal kriteria yang harus dimiliki oleh karyawan dalam organisasi. Di dalam standar juga terdapat aturan-aturan yang harus ditaati serta prosedur yang wajib juga ditaati oleh karyawan (Schneider, 2013).

Dimensi dukungan ditunjukkan dengan merefleksikan rasa percaya dan saling mendukung yang terdapat di dalam organisasi. Dukungan yang ada pada organisasi dapat memberikan iklim yang nyaman bagi setiap anggotanya. Karyawan merasa mendapat dukungan yang tinggi ketika ia merasa merupakan bagian dari organisasi dan ketika mendapat bantuan dari atasannya (Schneider, 2013)

Dimensi selanjutnya yaitu dimensi komitmen kelompok. Dimensi komitmen kelompok merupakan keinginan dari karyawan untuk tetap terus bertahan dan bekerja dalam organisasinya. Hal ini juga memengaruhi iklim organisasi (Schneider, 2013). Keempat dimensi tersebut digunakan untuk mengukur iklim organisasi.

\section{Komitmen Organisasi}

Komitmen organisasi merupakan hubungan psikologis antara karyawan dengan organisasi yang menyebabkan karyawan merasa ingin terus bekerja demi organisasinya sehingga ia tidak mudah meninggalkan organisasinya (Meyer, 1997). Komitmen organisasi juga bisa diartikan sebagai kepercayaan yang sangat kuat terhadap tujuan dan nilai-nilai dalam organisasi, keinginan sangat kuat untuk menjaga keanggotaan dalam organisasi dan kemauan untuk menerima dan menjadi bagian dalam suatu organisasi (Meyer, 1997).

Meyer (1997) menjelaskan dimensi dari komitmen organisasi terbagi menjadi tiga hal yaitu affective commitment, normative commitment dan continuance commitment. Affective commitment (komitmen afektif) dapat diartikan sebagai komitmen yang didasarkan pada adanya kelekatan emosi terhadap organisasi tempatnya bekerja. Selain itu, kelekatan perasaan tersebut juga didasarkan pada adanya kongruensi antara tujuan pribadi dari anggota organisasi dan juga tujuan dari organisasi tempat dirinya bekerja. 
Continuance commitment (komitmen berkelanjutan) merupakan komitmen yang didasarkan pada perhitungan untung dan rugi. Komitmen ini mendorong agar individu tetap dapat bertahan di organisasi. Komitmen jenis ini lebih fokus mengenai apa yang akan ia terima ketika berusaha keras dan juga apa yang dapat merugikan dirinya ketika memutuskan untuk meninggalkan suatu organisasi (Meyer, 1997).

Normative commitment (komitmen normatif) merupakan komitmen yang didasarkan pada standar dan juga perilaku yang diharapkan. Normative Commitment biasanya juga terjadi apabila individu menunjukkan kepatuhan, kehati-hatian dan juga formalitas (Meyer, 1997). Ketiga dimensi tersebut digunakan sebagai dasar dalam pengukuran komitmen organisasi dalam penelitian ini.

Tujuan dari penelitian ini yaitu mengetahui adanya hubungan iklim organisasi dengan komitmen terhadap organisasi di Universitas X. Berdasarkan tujuan tersebut maka pertanyaan yang diajukan dalam penelitian ini adalah apakah ada hubungan iklim organisasi dengan komitmen terhadap organisasi di Universitas $\mathrm{X}$ ? Hipotesis yang diajukan dalam penelitian ini adalah adanya hubungan positif dan signifikan antara iklim organisasi dengan komitmen organisasi di Universitas X.

\section{Metode}

Jenis penelitian ini merupakan penelitian kuantitatif. Desain atau rancangan penelitian ini adalah penelitian korelasional. Partisipan yang diikutsertakan merupakan karyawan Universitas X yang terdiri dari staf pengajar yang berjumlah 35 dan staf pendukung berjumlah 59. Pengambilan sampel menggunakan teknik purposive sampling. Peneliti mulai mempersiapkan penelitian sejak tanggal 20 Februari hingga 3 April 2018.

\section{Definisi Operasional}

Variabel penelitian ini adalah iklim organisasi dan komitmen organisasi. Iklim oganisasi adalah suatu kebermaknaan ataupun persepsi yang anggota organisasi rasakan dan berkaitan dengan praktik-praktik dan kebijakan dalam 
organisasi tersebut. Iklim organisasi dapat diukur melalui empat dimensi yaitu struktur, penghargaan, dukungan, komitmen kelompok dan standar, yang ditotalkan skornya ataupun diagregatkan. Semakin tinggi skor total atau skor agregat maka iklim organisasi tersebut semakin baik.

Komitmen organisasi merupakan hubungan psikologis yang terjalin antara anggota organisasi terhadap suatu organisasi. Komitmen organisasi diukur menggunakan tiga dimensi yang masing-masing dapat diagregatkan. Ketiga dimensi tersebut yaitu Affective Commitment, Normative Commitment dan Continuance Commitment. Kedua variabel tersebut menggunakan kuesioner dalam pengukurannya.

\section{Instrumen Penelitian}

Instrumen penelitian yang digunakan untuk mengukur iklim organisasi adalah OCQ (Organizational Climate Questionnaire) yang telah diadaptasi oleh Susanty (2012). Kuesioner iklim organisasi (OCQ) awalnya terdiri dari 21 butir tetapi setelah proses uji coba dilakukan maka jumlah butir menjadi 14 yang masing-masing terdiri dari dimensi standar, struktur, dukungan dan komitmen kelompok. Instrumen penelitian yang digunakan untuk mengukur komitmen organisasi adalah Organizational Commitment Questionnaire yang telah diadaptasi oleh Susanty (2012). Tidak ada butir yang tereliminasi pada kuesioner komitmen organisasi sehingga jumlah butir sebelum dan sesudah dilakukan uji coba adalah sama.

Tidak hanya staf pengajar, staf pendukung juga peneliti tanya kesediaannya untuk menjadi partisipan di dalam penelitian ini. Dari 101 data yang didapat peneliti hanya mengambil 94 karyawan dikarenakan terdapat 7 karyawan yang tidak mengisi data-data demografis sehingga tidak dapat dijadikan sampel. Data demografis subjek dapat dilihat pada Tabel 1.

\section{Tabel 1. Data Demografis Subjek}

\begin{tabular}{lc}
\hline Data Demografis & Jumlah Subjek \\
\hline Jenis Kelamin & \\
Pria & $51(54,3 \%)$ \\
Wanita & $43(45,7 \%)$ \\
\hline
\end{tabular}




\begin{tabular}{lc}
\hline Usia & $71(75,5 \%)$ \\
Dewasa Muda (20-40) & $23(24,5 \%)$ \\
Dewasa Tengah (40-65) & \\
\hline Lama Bekerja & $76(80,9 \%)$ \\
$1-10$ tahun & $13(13,8 \%)$ \\
$11-20$ tahun & $4(4,3 \%)$ \\
$21-30$ tahun & $1(1,1 \%)$ \\
\hline 30 tahun & \\
\hline
\end{tabular}

\section{Hasil dan Pembahasan}

\section{Korelasi Iklim Organisasi dan Komitmen terhadap Organisasi}

Berdasarkan hasil analisis korelasi dengan Spearman Correlation didapatkan nilai $r=0,694$ dengan $p=0,000<0,05$, sehingga dapat dikatakan bahwa terdapat hubungan yang signifikan dan positif antara iklim organisasi dan komitmen terhadap organisasi. Hasil korelasi parsial antara iklim organisasi dan komitmen terhadap organisasi dengan lama bekerja menghasilkan nilai $r=0,682$ dan $p=0,000<0,05$ yang berarti terdapat hubungan yang signifikan dan positif antara iklim organisasi dan komitmen terhadap organisasi. Hal tersebut menunjukkan bahwa semakin tinggi tingkat iklim organisasi maka semakin tinggi tingkat komitmen terhadap organisasi. Koefisien korelasi dalam penelitian ini dapat dikategorikan dalam taraf korelasi kuat. Data hasil korelasi antara Iklim Organisasi dan Komitmen terhadap organisasi dapat dilihat pada Tabel 2.

Tabel 2. Korelasi Antara Iklim Organisasi dan Komitmen terhadap Organisasi

\begin{tabular}{ccc}
\hline Tipe & R & Sig \\
\hline Korelasi & 0,694 & 0,000 \\
Korelasi Parsial & 0,682 & 0,000 \\
\hline
\end{tabular}

Dengan demikian, maka hipotesis penelitian diterima yaitu ada hubungan yang signifikan dan positif antara iklim organisasi dan komitmen terhadap organisasi pada karyawan Universitas X. Hal ini menunjukkan bahwa semakin tinggi tingkat iklim organisasi maka semakin tinggi pula tingkat komitmen terhadap organisasi, begitu pula sebaliknya semakin rendah tingkat iklim organisasi maka semakin rendah pula tingkat komitmen terhadap organisasi pada karyawan Universitas X. Selain itu, hasil penelitian yang dilakukan mendukung hasil penelitian Hosseini dan Talebian (2015) yang menyatakan bahwa terdapat 
hubungan yang signifikan dan positif antara iklim organisasi dengan komitmen terhadap organisasi di Universitas. Penelitian ini juga menghasilkan hal yang serupa dengan penelitian yang dilakukan oleh Permarupan, dkk (2013) yang menunjukkan bahwa iklim organisasi dengan komitmen organisasi memiliki hubungan yang juga positif dan signifikan.

Terdapat perbedaan koefisien korelasi pada perhitungan korelasi biasa dengan teknik parsial. Jika sebelumnya korelasi tanpa mempertimbangkan faktor lama bekerja menghasilkan nilai $r=0,694$, maka perhitungan dengan teknik parsial dapat menurunkan koefisien korelasi menjadi $r=0,682$. Jika dilihat berdasarkan faktor lama bekerja terhadap korelasi iklim organisasi dan komitmen terhadap organisasi pada karyawan Universitas $\mathrm{X}$, dapat dikatakan tidak ada pengaruh yang terlalu besar dari faktor lama bekerja.

\section{Iklim Organisasi di Universitas X}

Peneliti menggunakan tiga kategori untuk menentukan tinggi atau rendahnya iklim organisasi yang dimiliki oleh karyawan Universitas X, kategori tersebut terdiri dari rendah, sedang, dan tinggi. Nilai rata-rata pada iklim organisasi sebesar 75,27. Pemaparan data tinggi atau rendahnya iklim organisasi yang dimiliki oleh karyawan Universitas X dapat dilihat pada Tabel 3.

Tabel 3. Frekuensi dan Presentasi Hasil Pengukuran Iklim Organisasi

\begin{tabular}{ccccc}
\hline Skor & Kategori & Frekuensi & Presentase (\%) & Rata-rata \\
\hline$>77$ & Tinggi & 54 & 57,4 & \\
$49-77$ & Sedang & 33 & 35,1 & \\
$<49$ & Rendah & 7 & 7,4 & $\mathbf{7 5 , 2 7}$ \\
\hline
\end{tabular}

Berdasarkan pengkategorian pada Tabel 3, maka dapat dikatakan bahwa karyawan Universitas X memiliki keterikatan kerja yang masuk dalam kategori sedang. Hal ini berarti karyawan Universitas X merasakan suatu kebermaknaan yang berhubungan dengan kebijakan dan prosedur dalam Universitas X. Karyawan Universitas X merasa bahwa peran, tanggung jawab, dan struktur organisasi terkait pekerjaannya sudah cukup jelas. Imbalan, upah, atau promosi yang diterima oleh karyawan di Universitas X dirasa sesuai dengan kinerjanya. Karyawan Universitas 
$\mathrm{X}$ juga merasa bangga dengan tempat ia bekerja serta memiliki pemahaman mengenai tujuan universitas.

\section{Komitmen terhadap Organisasi di Universitas X}

Peneliti menggunakan tiga kategori untuk menentukan tingkat komitmen terhadap organisasi pada karyawan Universitas X. Kategori terdiri dari rendah, sedang dan tinggi. Nilai rata-rata pada persepsi kepemimpinan transformasional sebesar 40,04. Pemaparan data tingkat komitmen terhadap organisasi pada karyawan Universitas X dapat dilihat pada Tabel 4.

Tabel 4. Frekuensi dan Presentasi Hasil Pengukuran Komitmen terhadap Organisasi

\begin{tabular}{ccccc}
\hline Skor & Kategori & Frekuensi & Presentase (\%) & Rata-rata \\
\hline$>40,3$ & Tinggi & 48 & $51,1 \%$ & \\
$25,7-40,3$ & Sedang & 40 & $42,6 \%$ & \\
$<25,7$ & Rendah & 6 & $6,4 \%$ & 40,04 \\
& & & $100 \%$ & \\
\hline
\end{tabular}

Berdasarkan pengkategorian tersebut, maka dapat dikatakan bahwa karyawan Universitas $\mathrm{X}$ memiliki komitmen terhadap organisasi yang masuk dalam kategori sedang. Hal ini berarti karyawan Universitas X cukup dapat mengidentifikasi dirinya dengan nilai, aturan, serta tujuan organisasi.

\section{Analisis Korelasi Dimensi Iklim Organisasi dan Komitmen terhadap Organisasi}

Analisis korelasi pada setiap dimensi iklim organisasi dan komitmen terhadap organisasi menunjukkan bahwa seluruh dimensi saling berkaitan dengan hubungan positif yang signifikan. Hasil analisis korelasi tiap dimensi iklim organisasi dan komitmen terhadap organisasi dapat dilihat pada Tabel 5.

Tabel 5. Korelasi Dimensi Iklim Organisasi dan Komitmen terhadap Organisasi

\begin{tabular}{lcc}
\hline Aspek & R & Sig \\
\hline Dimensi Struktur - Komitmen Afektif & 0,303 & 0,003 \\
Dimensi Struktur - Komitmen Berkelanjutan & 0,252 & 0,014 \\
Dimensi Struktur - Komitmen Normatif & 0,294 & 0,004 \\
Dimensi Standar - Komitmen Afektif & 0,604 & 0,000 \\
Dimensi Standar - Komitmen Berkelanjutan & 0,416 & 0,000 \\
Dimensi Standar - Komitmen Normatif & 0,454 & 0,000 \\
Dimensi Tanggung Jawab - Komitmen Afektif & 0,501 & 0,000 \\
Dimensi Tanggung Jawab - Komitmen Berkelanjutan & 0,538 & 0,000 \\
Dimensi Tanggung Jawab - Komitmen Normatif & 0,654 & 0,000 \\
Dimensi Pengakuan - Komitmen Afektif & 0,463 & 0,000 \\
Dimensi Pengakuan - Komitmen Berkelanjutan & 0,423 & 0,000 \\
Dimensi Pengakuan - Komitmen Normatif & 0,461 & 0,000 \\
\hline
\end{tabular}




\begin{tabular}{lll}
\hline Dimensi Dukungan - Komitmen Afektif & 0,490 & 0,000 \\
Dimensi Dukungan - Komitmen Berkelanjutan & 0,373 & 0,000 \\
Dimensi Dukungan - Komitmen Normatif & 0,429 & 0,000 \\
Dimensi Komitmen - Komitmen Afektif & 0,407 & 0,000 \\
Dimensi Komitmen - Komitmen Berkelanjutan & 0,468 & 0,000 \\
Dimensi Komitmen - Komitmen Normatif & 0,502 & 0,000 \\
\hline
\end{tabular}

Peneliti juga mencari hubungan antara masing-masing dimensi iklim organisasi dan komponen komitmen terhadap organisasi. Hasil ini memperkuat adanya hubungan antara iklim organisasi dan komitmen terhadap organisasi. Dari hubungan antar dimensi, terdapat korelasi yang menonjol yaitu dimensi tanggungjawab dan komitmen normatif dengan korelasi tertinggi dan dimensi struktur dan komitmen berkelanjutan dengan korelasi terendah. Korelasi dimensi tanggung jawab dan komponen komitmen normatif sebesar $r=0,654$ dan $p=$ 0,000 , yang dapat diartikan bahwa kemandirian staf pengajar dan pendukung dalam melaksanakan pekerjaannya berhubungan positif dengan perasaan keharusan untuk bertahan di universitas.

Korelasi dimensi struktur dan komitmen berkelanjutan sebesar $r=0,252$ dan $p=0,014$, yang dapat diartikan bahwa kejelasan peran dan tanggung jawab dalam pekerjaan berhubungan positif dengan keinginan untuk bertahan karena staf pengajar dan pendukung mempertimbangkan keadaan untung dan rugi yang diberikan universitas.

\section{Analisis Korelasi berdasarkan Demografis Subjek Penelitian Korelasi berdasarkan Lama Bekerja}

Selanjutnya, peneliti membagi partisipan menjadi tiga kelompok berdasarkan lama bekerja. Hasil analisis korelasi berdasarkan masa lama bekerja dapat dilihat pada Tabel 7.

Tabel 7. Korelasi Berdasarkan Lama Kerja

\begin{tabular}{ccc}
\hline Lama Kerja (tahun) & $\mathbf{R}$ & Sig \\
\hline $1-10$ & 0,701 & 0,000 \\
$11-20$ & 0,783 & 0,002 \\
$21->30$ & 0,400 & 0,505
\end{tabular}

Berdasarkan tabel di atas, dapat dilihat bahwa adanya hubungan yang signifikan dan positif antara iklim organisasi dan komitmen terhadap organisasi pada kelompok partisipan yang memiliki masa lama kerja dari 1 hingga 10 tahun 
dengan nilai $r=0,701$ dan $p=0,000$. Pada kelompok partisipan yang memiliki masa lama kerja dari 11 hingga 20 tahun juga menunjukkan adanya hubungan yang positif dan signifikan antara iklim organisasi dan komitmen terhadap organisasi dengan nilai $r=0,783$ dan $p=0,002$. Sedangkan, pada kelompok partisipan yang memiliki masa lama kerja dari 21 hingga lebih dari 30 tahun tidak terdapat hubungan yang signifikan antara iklim organisasi dan komitmen terhadap organisasi dengan nilai $r=0,400$ dan $p=0,505$. Korelasi antara iklim organisasi dan komitmen terhadap organisasi pada kelompok partisipan yang memiliki masa lama kerja 11 hingga 20 tahun menghasilkan nilai korelasi yang lebih tinggi dibandingkan dengan kelompok partisipan yang memiliki masa lama kerja 1 hingga 10 tahun.

\section{Kesimpulan dan Saran}

\section{Kesimpulan}

Berdasarkan hasil analisis dan pembahasan, maka peneliti menyimpulkan bahwa hipotesis penelitian diterima, yaitu terdapat hubungan yang signifikan dan positif antara iklim organisasi dan komitmen terhadap organisasi pada karyawan di Universitas $\mathrm{X}$ dengan mempertimbangkan faktor lama bekerja. Iklim organisasi di Universitas $\mathrm{X}$ berada pada kategori sedang dan komitmen terhadap organisasi karyawan Universitas X juga berada pada kategori sedang. Seluruh dimensi iklim organisasi berhubungan positif dan signifikan dengan seluruh komponen komitmen terhadap organisasi.

\section{Saran}

Berdasarkan hasil penelitian ini, Universitas X dapat meningkatkan iklim organisasi di universitas, karena iklim organisasi dapat memengaruhi tingkat komitmen karyawan terhadap organisasi. Universitas $\mathrm{X}$ dapat memberikan penghargaan dan insentif bagi staf pengajar dan pendukung yang dapat mencapai KPI. Bagi karyawan yang belum mencapai KPI, perlu mendapatkan pelatihan dan pengembangan diri yang sesuai dengan fungsi tugasnya. Organisasi perlu menciptakan iklim yang kekeluargaan dalam bentuk saling menghargai, memodifikasi kegiatan gathering yang sudah dilakukan agar tujuan kebersamaan 
di dalam relasi antar individu dapat tercapai.

Penelitian selanjutnya mengenai hubungan iklim organisasi dapat dikaitkan dengan variabel lain seperti kepuasan kerja, work engagement dan kinerja karyawan. Selain itu, peneliti selanjutnya disarankan untuk meneliti lebih lanjut mengenai besarnya pengaruh iklim organisasi terhadap variabel komitmen terhadap organisasi.

\section{DAFTAR PUSTAKA}

Adeniji, A. A. (2011). Organizational climate as a predictor of employee job satisfaction: Evidence from Covenant University. Business intelligence journal, 4(1), 151-166.

Ausri, S. R., Susilo, H., \& Sulistyo, M. C. W. (2018). Pengaruh Iklim Organisasi Terhadap Komitmen Organisasional Dengan Kepuasaan Kerja Sebagai Variabel Intervening. Jurnal Administrasi Bisnis, Vol. 60(1), 172-179.

Capricornia, Jeane. Pengaruh Iklim Organisasi Dan Stres Kerja Terhadap Komitmen Organisasi Dan Dampaknya Pada Kepuasan Kerja Karyawan Pt Perdana Jatiputra. Binus University, Jakarta, Indonesia, jeane.effendi@yahoo.com

Dyne, L. V., Graham, J. W., \& Dienesch, R. M. (1994). Organizational citizenship behavior: Construct redefinition, measurement, and validation. Academy of Management Journal, Vol 37(4), 765-802.

Ehrhart, M. G., Schneider, B., \& Macey, W. H. (2013). Organizational climate and culture: An introduction to theory, research, and practice. Routledge.

Hosseini, M., Talebian, N. H. Correlation between organizational 72commitment and organizational climate of physical education 73teachers of schools of Zanjan. Int J Sport Stud 2015;5(2): 181-5.

Junandi, S. \& Maryono. (2012). Pengaruh Iklim Organisasi Terhadap Kinerja Pustakawan Universitas Gajah Mada. Jurnal Sangkakala, Vol. 12 (12), 2433.

Kambey, F., Adolfina, \& Trang, I. (2016). Komitmen Organisasi, Kompensasi, Dan Iklim Organisasi Pengaruhnya Terhadap Kepuasan Kerja Karyawan Studi Pada PT. Telkom TBK. Manado. Jurnal Ekonomi Manajemen Bisnis dan Akuntansi, Vol. 4(5), 467-477. 
Kingkin, P., Rosyid, H.F., \& Arjanggi, R. (2016). Kepuasan Kerja Dan Masa Kerja Sebagai Prediktor Komitmen Organisasi Pada Karyawan PT. Royal Korindah Di Purbalingga. Proyeksi, Vol. 5 (1), 17-32.

Meyer, J. P., \& Allen, N. J. (1997). Commitment in the Workplace. Sage Publications.

Meyer, J. P., Allen, N. J., \& Gellatly, I. R. (1990). Affective and continuance commitment to the organization: Evaluation of measures and analysis of concurrent and time-lagged relations. Journal of applied psychology, 75(6), 710.

Miroshnik, V. (2013). Organizational culture and commitment: Transmission in multinationals. Springer.

Permarupan, P. Y., Saufi, R. A., Kasim, R. S. R., \& Balakrishnan, B. K.P.D. (2013). The impact of organizational climate on employee's work passion and organizational commitment. Social and Behavioral Sciences, 107, 8895.

Rahmawati, N., \& Prasetyo, R. (2017). Hubungan Antara Iklim Organisasi Dengan Komitmen Organisasi Pada Petugas Pemasyarakatan Kelas 1 Semarang. Jurnal Empati, Vol. 6(1), 317-321.

Starnes, B. J., Truhon, S. 2016. A primer organizational commitment. Milwaukee, WI: Human Development and Leadership Division, (ASQ) American Society for Quality.

Suryani, I. (2018). Factors Affecting Organizational Commitment. Jurnal Manajemen Dan Inovasi, Vol. 9 (1), 26-34.

Susanty, E. (2012). Pengaruh Iklim Organisasi Terhadap Kepuasan Kerja dan Komitmen Karyawan pada Universitas X. (Tesis tidak dipublikasikan). Bogor: Intitut Pertanian Bogor. 